\title{
Validation Evidence for the Work Domain Satisfaction Scale in Two Languages
}

\author{
Nicole Bérubé ${ }^{1}$, Magda B. L. Donia ${ }^{2}$, Marylène Gagné ${ }^{3}$, Nathalie Houlfort ${ }^{4} \&$ Elena Lvina $^{5}$ \\ ${ }^{1}$ Department of Management \& Economics, Royal Military College of Canada, Kingston, Ontario, Canada \\ ${ }^{2}$ Telfer School of Management, University of Ottawa, Ottawa, Ontario, Canada \\ ${ }^{3}$ School of Psychology, University of Western Australia, Crawley, WA \\ ${ }^{4}$ Department of Psychology, Université du Québec à Montréal, Montréal, Québec, Canada \\ ${ }^{5}$ Haub School of Business, Saint Joseph's University, Philadelphia, PA, USA \\ Correspondence: Nicole Bérubé, Department of Management \& Economics, Royal Military College of Canada, \\ Kingston, Ontario, Canada. Tel: 1-613-541-6000.E-mail: nicole.berube@rmc.ca
}

Received: April 27, 2016

Accepted: May 19, 2016

Online Published: June 23, 2016

doi:10.5539/ijps.v8n3p26

URL: http://dx.doi.org/10.5539/ijps.v8n3p26

\begin{abstract}
We used the samples of six studies to validate the Work Domain Satisfaction Scale (WDSS), a global, five-item and mid-level measure of work domain well-being. English and French versions of the scale were included in the studies to assess the stability of the instrument across these languages. Confirmatory factor analysis yielded a one-factor structure, which was shown invariant across languages and samples. Test-retest reliability of the scale was high, indicating that it measures a stable construct over time. Confirmatory factor analysis also provided evidence that satisfaction with work, measured with the WDSS, is related, but conceptually and empirically distinct from both life satisfaction and job satisfaction. The WDSS was also correlated in predictable ways with affective organizational commitment, a measure of how attached people are to their organizations. Work domain satisfaction also explained a significant amount of variance in affective organizational commitment, beyond job satisfaction. Moreover, the WDSS was positively related to inclusion of work into the self, a psychological variable that reflects the importance of work in the lives of individuals. The results indicate that the WDSS is a reliable, stable, and valid mid-level measure of satisfaction with work as a domain within people's lives.
\end{abstract}

Keywords: work domain, satisfaction scale, validation, English, French, mid-level construct

\section{Introduction}

Work is central to people's lives and to their well-being (Blustein, 2008; Diener, Emmons, Larsen, \& Griffin, 1985; Ryff \& Keyes, 1995), in both paid employment situations and volunteer work contexts (Diener, Suh, Lucas, \& Smith, 1999; Thoits \& Hewitt, 2001). Walters and her colleagues (Walters, French, Eyles, Lenton, Newbold, \& Mayr, 1997) argued that to understand how work influences well-being, it is essential to take into account the breadth of the work domain, which includes not only employment activity but all forms of unpaid labour. However, much of what we know about how people feel about work is based on their level of satisfaction with a particular job. Consequently, the impressive body of literature on job satisfaction focuses mostly on the employment context and thus, on how people feel about a particular job, rather than on how people feel about work as a life domain (e.g., Connolly \& Viswesvaran, 2000; Judge, Bono, Thoresen, \& Patton, 2001; Judge, Heller, \& Mount, 2002). Although the job satisfaction construct is well-suited to investigations within a specific employment context, it comprises limitations for investigating people's higher-level feelings about work as a domain in their life. This becomes an issue when assessing the satisfaction people feel regarding their work when such satisfaction includes activities that extend beyond the scope of the job. Therefore, our objective was to test a short measure of work domain satisfaction that would enable us to capture cognitive appraisals of well-being at the domain level of analysis. To this end, we validated the Work Domain Satisfaction Scale (WDSS), a short, global measure of work domain satisfaction, a mid-level construct that reflects how well people feel about all work-related activities in their lives. 


\subsection{Work and the Work Domain}

Our interest in work domain satisfaction stems from the well-recognized need for work-related mental health research (e.g., Kelloway \& Day, 2005; McDaid, Curran, \& Knapp, 2005). Although Work Domain Satisfaction (WDS) is conceptually related to life and job satisfactions, the three constructs are distinct. Life satisfaction lies at the highest and most global level. It reflects a global cognitive appraisal of one's overall well-being (Pavot, Diener, Colvin, \& Sandvik, 1991), which is considered stable throughout life (Diener, 1994; Lucas, Diener, \& Suh, 1996; Oishi \& Diener, 1996; Pavot et al., 1991). The "life" level of analysis includes all the domains in an individual's life, such as spirituality, leisure, and work, among others. We maintain that work is an important life domain which can comprise various work activities, including both paid and unpaid labour and thus, work domain satisfaction assesses well-being with all of the work-related activities of an individual. At the lowest level of analysis, job satisfaction represents well-being within a job: a particular contractual work agreement in exchange for remuneration.

Dispositions and beliefs shape individual experiences about work and what constitutes work (Wrzesniewski, Dutton, \& Debebe, 2003) and thus, what is perceived as work depends on the individual's perception and values (Eichler \& Matthews, 2010). In contrast to a job, where the activities included are contractually determined by the employer in exchange for pay, the work domain level of analysis includes a broader range of work activities. At this level, we define work more widely as human labour, which may include employment, self-employment for remuneration, and volunteer work.

Engaging in work activities that are congruent with one's values can help contribute to a sense of well-being about work. As such, Ros, Schwartz, and Surkiss (1999) argued that the various types of work activities people engage in serve to satisfy needs linked to their values (e.g., self-direction, hedonism, power, security, achievement, and stimulation). Sometimes people may fulfill these values by engaging in more than one type of work. For example, a person who values security, stimulation, and benevolence may be employed in a well-paid, but boring job that he feels makes little difference in the lives of others. This job would gratify the individual's need for security but leave unfulfilled the person's needs for stimulation and benevolence. However, let's say that the same individual also volunteers as a firefighter, which fulfills the individual's needs for stimulation (fighting fires) and benevolence (saving lives, helping others). Only measuring his job satisfaction would provide an incomplete picture of this person's well-being in the work domain. As it is becoming more and more common for people to hold more than one job (sometimes one that is employed and one that is self-employed), or to have a job and volunteer, we need a measure that takes into account these multiple roles when assessing satisfaction with the work domain.

Assessing both job and work domain satisfaction would provide a way to determine whether or not people are managing their work domain activities in ways that enhance their well-being, thus providing information on well-being that job satisfaction alone could not provide. Moreover, work domain satisfaction would be a very important measure for those individuals not engaged in paid employment as it remains an important part of people's lives and well-being during periods of unemployment (McKee-Ryan, Song, Wanberg, \& Kinicki, 2005), after retirement (e.g., Kim \& Feldman, 2000), or for individuals who become involved in volunteer work (Thoits \& Hewitt, 2001).

\subsection{The Work Domain Satisfaction Scale (WDSS)}

We sought to contribute a short, quickly administered measure that would enable us to capture the essence of a cognitive appraisal of work-related well-being. We began with a literature search in English and French (determined by the language competencies of the authors) to decide whether the measure would be based on an existing one or developed from scratch. We concluded that a good option would be to validate a French-language measure initially adapted by Blais, Lachance, Forget, Richer and Dulude (1991). This measure had been used successfully in previous publications (Lévesque, Blais, \& Hess, 2004a, 2004b) but had not been the object of a formal validation study. The measure is an adaptation of the Satisfaction with Life Scale (SWLS; Diener et al., 1985) to the work domain. The SWLS is a short five-item scale that has excellent psychometric properties (test-retest reliability $=.82$, Cronbach's $\alpha=.87$; Diener et al., 1985). In addition, the SWLS was found to be invariant across age groups and uncorrelated with social desirability (Pons, Atienza, Balaguer, \& Garica-Merita, 2000). This suggested that an adaptation of this scale to the work domain would be likely to have similar psychometric properties.

Blais and his colleagues (1991) adapted the five items of the SWLS to reflect satisfaction with work in the French language, and subsequently used it as a proxy of job satisfaction in two studies on the topic of work motivation (Lévesque, Blais, \& Hess, 2004a, 2004b). These studies were all cross-sectional, and used small 
samples (146 to 184 respondents) of exclusively French speaking, predominantly male workers from either Gabon (Africa) or Quebec (Canada). In both of these studies, the reported reliabilities of the work satisfaction instrument were relatively low despite the removal of one item (Cronbach's $\alpha$ 's $=.61$ and .65 ); they correlated at .56 and .57 with the SWLS, and were uncorrelated with the Marlowe-Crown social desirability measure. These earlier investigations therefore provide good initial evidence that work domain satisfaction is related but distinct from life satisfaction.

We translated the Blais et al. (1991) adaptation of the SWLS in English and named it the Work Domain Satisfaction Scale (WDSS), enabling us to collect validation evidence for the instrument in two languages. We also clarified the stem of the items to help respondents identify the boundaries of the work domain. To establish the conceptual distinctiveness of the WDSS relative to job satisfaction measures, we compared its items with those of widely used job satisfaction instruments. Since the WDSS is a multiple-item global scale, we focused on instruments of this type (instead of focusing on "facet" instruments), including the Overall Job Satisfaction Scale (Brayfield \& Rothe, 1951), the Michigan Organizational Assessment Questionnaire job satisfaction subscale (Cammann, Fichman, Jenkins, \& Klesh, 1979), Hoppock's satisfaction scale (Hoppock, 1935), and the Job in General Scale (Ironson, Smith, Brannick, Gibson, \& Paul, 1989). We found that the wording of items in each of these scales was clearly job-related, whereas the items in the WDSS positioned work as a more general function in an individual's life.

Although the WDSS is a global instrument, we also sought to establish the conceptual distinctiveness of the WDSS from job satisfaction subscales that measure the "nature of the work itself". These subscales often refer to the design of the tasks that people do in their job. To this end, we examined the items of "work itself" subscales of the most popular facet job satisfaction scales: the Job Descriptive Index (JDI; Smith, Kendall, \& Hulin, 1969), the Minnesota Satisfaction Questionnaire (MSQ; Weiss, Dawis, England, \& Lofquist, 1967), and the Job Satisfaction Survey (JSS; Spector, 1985, 1997). In each of these scales, we found that the facet measuring the nature of the work, or the work itself, refers clearly to the intrinsic value, or enjoyment, of tasks accomplished in a particular employment situation, rather than to general well-being in relation to the domain of work. The WDSS is detailed in Table 1.

Table 1. English and French versions of the Work Domain Satisfaction Scale (WDSS)

\begin{tabular}{|c|c|}
\hline English & French \\
\hline $\begin{array}{l}\text { 1. In general, the type of work I do corresponds } \\
\text { closely to what I want in life. }\end{array}$ & $\begin{array}{l}\text { 1. En général, le type de travail que je fais } \\
\text { correspond de près à ce que je veux dans la vie. }\end{array}$ \\
\hline $\begin{array}{l}\text { 2. The conditions under which I do my work are } \\
\text { excellent. }\end{array}$ & $\begin{array}{l}\text { 2. Les conditions dans lesquelles je fais mon travail } \\
\text { sont excellentes. }\end{array}$ \\
\hline 3. I am satisfied with the type of work I do. & 3. Je suis satisfait(e) du type de travail que je fais. \\
\hline $\begin{array}{l}\text { 4. Until now, I have obtained the important things I } \\
\text { wanted to get from my work. }\end{array}$ & $\begin{array}{l}\text { 4. Jusqu'à maintenant, j'ai obtenu les choses } \\
\text { importantes que je voulais retirer de mon travail. }\end{array}$ \\
\hline $\begin{array}{l}\text { 5. If I could change anything about work, I would } \\
\text { change almost nothing. }\end{array}$ & $\begin{array}{l}\text { 5. Si je pouvais changer quoi que ce soit concernant } \\
\text { le travail, je n'y changerais presque rien. }\end{array}$ \\
\hline
\end{tabular}

Notes. Stem in English: The following 5 statements are about how you feel about work as a general aspect of your life. Circle the number from 1 (completely disagree) to 7 (completely agree) that best expresses the degree to which you agree with each statement.

Stem in French: Les 5 énoncés suivants concernent la place du travail en tant qu'un aspect de votre vie. Encerclez le chiffre de 1 (complètement en accord) à 7 (complètement en désaccord) qui correspond le mieux à votre réponse. 


\section{Method}

We collected data from six different samples to verify the factor structure of the WDSS and its invariance across samples and language. We included a longitudinal sample to verify the stability of work domain satisfaction across time. Participants in all samples received a survey either through an online survey management system or in a paper-and-pencil format directly from the researchers and returned the surveys directly to the researchers either in French or in English depending on their spoken language. Participation was confidential and voluntary.

\subsection{Measures}

\subsubsection{Work Domain Satisfaction Scale}

Participants in all samples rated the five items of the WDSS using a 1 (strongly disagree) to 7 (strongly agree) Likert scale. Participants in five of the samples used the French version of the scale, whereas the English version of the sample was used by participants in four of the samples.

\subsubsection{Satisfaction with Life Scale (SWLS)}

To establish the distinctiveness of the work domain satisfaction scale from satisfaction with life, participants in one of the samples rated the five items of the SWLS (Diener et al., 1985), using a 1 (strongly disagree) to 7 (strongly agree) Likert scale.

\subsubsection{Overall Job Satisfaction (OJS)}

To establish the relationship and distinctiveness between work domain satisfaction and job satisfaction, participants in two of the samples rated the five items of the short version of the OJS (Brayfield \& Rothe, 1951) using a 1 (strongly disagree) to 7 (strongly agree) Likert scale. Previous research found this instrument had good reliability in previous studies with average internal consistency ranging from .82 to .86 (Bono \& Judge, 2003; Judge, Bono, \& Locke, 2000).

\subsubsection{Work-Related Outcomes}

To provide evidence of predictive validity for the WDSS, we sought to establish whether the WDSS would be related in predictable ways to outcomes related to work. We concluded that since the samples consisted of employed workers, the WDSS should account for variance in known correlates of work-related satisfaction. To this end we included the following measures.

Perceived work competence (Thomas \& Velthouse, 1990), a known component of psychological empowerment (Spreitzer, 1995, 1996) was included in two of the samples used in this study. Participants rated the four items of the perceived competence subscale of the psychological empowerment scale on a 1 (strongly disagree) to 7 (strongly agree) Likert scale. In previous studies, this subscale was found to be positively related to job satisfaction (e.g., Morrison, Jones, \& Fuller, 1997; Wang \& Lee, 2009) and had very good reliability with average internal consistency over .80 (Spreitzer \& Quinn, 2001).

Affective organizational commitment (Meyer \& Allen, 1991) reflects the desire to remain in an organization based on positive feelings while working there and is a strong correlate of overall job satisfaction $(\rho=.65$; Meyer, Stanley, Herzcovitch, \& Topolnytsky, 2002). In their review, Allen and Meyer (1996) reported median reliabilities of 0.79 for this measure across 40 studies. This measure was used in three of the samples used in this study and participants rated the six items on a 1 (strongly disagree) to 7 (strongly agree) Likert scale. Since this measure was used in samples where both job satisfaction and work domain satisfaction were measured, we expected that the WDSS would explain additional variance in affective organizational commitment, beyond job satisfaction.

Finally, to verify whether the WDSS is associated with an indicator of work importance, we included in one of the samples, a measure of inclusion of work into the self (Aron, A., Aron, E., \& Smollan, 1992), a single-item pictorial assessment that asks respondents to evaluate the extent to which they feel close to, or intimately involved in work. 


\subsection{Participants}

The characteristics of participants in our samples are summarized in Table 2. Each of the 6 samples was used in a single study and thus, the samples from 6 different studies were used. All the studies were cross-sectional with the exception of the study for Sample 1, which was longitudinal. Respondents in this sample were employees (e.g., teachers, bank tellers, lawyers, secretaries) who completed a survey (Time 1) and were invited to complete a second survey 6 months later (Time 2). A total of 100 participants completed both questionnaires, yielding 97 usable matched questionnaires. No statistical differences in participant characteristics were found between participants who completed both questionnaires and those who responded only at Time 1 .

All respondents in the samples had been employed for at least one year and thus, were familiar with the concept of job satisfaction. Average organizational tenure of the employees in the samples ranged from one year to 15 years. The retirees in Sample 2 had worked an average of 28.2 years prior to retiring. Generally, respondents in the samples were Canadian residents. Respondents in Samples 1, 3 and 5 resided in the Province of Quebec, those in Sample 3 resided in Ontario and those in Samples 4 and 6 resided in various locations across Canada.

Table 2. Characteristics of samples used in the present study

\begin{tabular}{|c|c|c|c|c|c|}
\hline Sample & Description of respondents & $\begin{array}{l}\text { Sample } \\
\text { Size }\end{array}$ & Languages & $\begin{array}{l}\text { Gender } \\
(\% \text { men })\end{array}$ & $\begin{array}{l}\text { Age } \\
\text { (mean) }\end{array}$ \\
\hline \multirow[t]{2}{*}{1} & \multirow{2}{*}{$\begin{array}{l}\text { Employees of six organizations in } \\
\text { the public and private sectors }\end{array}$} & $202(\mathrm{~T} 1)$ & \multirow[t]{2}{*}{ French } & $52 \%$ & 43 \\
\hline & & $97(\mathrm{~T} 2)$ & & $49 \%$ & 42 \\
\hline 2 & $\begin{array}{l}\text { Retired employees (public sector: } \\
68 \% \text {; private sector: } 32 \% \text { ) }\end{array}$ & 103 & French & $45 \%$ & 62 \\
\hline 3 & $\begin{array}{l}\text { Employees ( } 89 \% \text { non-managers) } \\
\text { of a medium-sized manufacturing } \\
\text { company }\end{array}$ & 167 & English & $58 \%$ & 44 \\
\hline 4 & $\begin{array}{l}\text { Employees }(76.4 \% \\
\text { non-managers) of a large } \\
\text { transportation company }\end{array}$ & 2276 & $\begin{array}{l}\text { English (2045) } \\
\text { French (231) }\end{array}$ & See note & 39 \\
\hline 5 & $\begin{array}{l}\text { Full-time undergraduate students, } \\
\text { employed part-time }\end{array}$ & 52 & English & $50 \%$ & 21 \\
\hline 6 & $\begin{array}{l}\text { Middle managers of a large } \\
\text { private sector service organization }\end{array}$ & 147 & $\begin{array}{l}\text { English (115) } \\
\text { French (32) }\end{array}$ & $45 \%$ & 43 \\
\hline
\end{tabular}

Note. Due to an online coding error, gender was not recorded.

\section{Analyses and Results}

\subsection{Reliability}

Internal reliabilities, means, and standard deviations for each sample are reported in Table 3. Internal reliabilities for the WDSS in all our samples were acceptable, with Cronbach's alphas ranging from .73 to .87 for all but Sample 5, where the internal consistency (.66) was less than .70. Although this may be an artifact of the small sample size and the results were close to the generally acceptable cut-off for internal consistency (Streiner, 2003), we explored whether removing one item would improve the internal consistency for that sample. Removing the last item ("If I could change anything about work, I would change almost nothing") improved the internal consistency for this sample to .72 . Overall, the results indicate that the WDSS is generally reliable across samples. 
Table 3. Means, standard deviations and reliabilities and correlations coefficients

\begin{tabular}{|c|c|c|c|c|c|c|}
\hline Sample & $\begin{array}{l}\text { Mean } \\
\text { WDSS }\end{array}$ & $\begin{array}{l}\text { Standard } \\
\text { deviation } \\
\text { WDSS }\end{array}$ & $\begin{array}{l}\text { Internal } \\
\text { consistency, } \\
\text { (Cronbach's } \\
\text { a) WDSS }\end{array}$ & $\begin{array}{l}\text { Other } \\
\text { measures } \\
\text { (Note 3) }\end{array}$ & $\begin{array}{l}\text { Internal } \\
\text { consistency } \\
\text { (Cronbach's } \alpha) \\
\text { of other measures }\end{array}$ & $\begin{array}{l}\text { Correlation } \\
\text { between } \\
\text { WDSS and } \\
\text { other measures }\end{array}$ \\
\hline $1, \mathrm{~T} 1$ & 4.49 & 1.14 & .82 & SWLS & .86 & $.49 * *$ \\
\hline $1, \mathrm{~T} 2$ & 4.53 & 1.17 & $\begin{array}{l}.85(\mathrm{~T} 2) \\
\text { see note } 1\end{array}$ & SWLS & $\begin{array}{l}.91(\mathrm{~T} 2) \\
\text { see note } 2\end{array}$ & $.53^{* *}$ \\
\hline 2 & 5.19 & 1.18 & .87 & IWS & $\mathrm{n} / \mathrm{a}$ & $.24 *$ \\
\hline 3 & 4.13 & 1.13 & .73 & $\begin{array}{l}\text { PWC } \\
\text { AC }\end{array}$ & $\begin{array}{l}.86 \\
.79\end{array}$ & $\begin{array}{l}.61^{* *} \\
.18^{*}\end{array}$ \\
\hline 4 & 3.81 & 1.14 & .74 & PWC & .79 & $.31^{* *}$ \\
\hline 5 & 3.53 & 0.80 & .66 & OJS & .78 & $.34 *$ \\
\hline 6 & 4.77 & 1.06 & .87 & $\begin{array}{l}\text { OJS } \\
\mathrm{AC}\end{array}$ & $\begin{array}{l}.83 \\
.70\end{array}$ & $\begin{array}{l}.59^{* *} \\
.49^{* *}\end{array}$ \\
\hline
\end{tabular}

Notes. 1. Test-retest reliability of WDSS for Sample 1, T1 to T2 was $\mathrm{r}=.77, \mathrm{p}<.01$.

2. Test-retest reliability of SWLS for Sample 1, T1 to T2 was $r=.82, p<.01$.

3. SWLS (Satisfaction with Life); IWS (Inclusion of Work into the self); PWC (Perceived Work Competence); AC (Affective Commitment); OJS (Overall Job Satisfaction).

$* p<0.05 * * p<0.01$.

\subsection{Factor Analysis}

To examine the structure of the WDSS we conducted a confirmatory factor analysis with maximum likelihood estimation using EQS 6.1 on the combined raw data set of all six samples. A first model was tested by loading each of the 5 items onto one latent factor. This model yielded a poor fit, $\chi^{2}(5)=919.11, p<.001, \mathrm{NNFI}=.54$, $\mathrm{CFI}=.77, \mathrm{AGFI}=.64, \mathrm{RMSEA}=.25$. Based on LM tests, we freed up two correlations between errors, which significantly improved the fit of the model to the data, $\chi^{2}(3)=14.00, p<.05$, NNFI $=.99$, CFI $=.99$, AGFI $=.99$, RMSEA $=.04$. We also conducted a CFA excluding sample 4 , which was much larger, to ensure that it did not dominate the analyses, and found very little change in fit, $\chi^{2}(5)=15.84, p<.05$, NNFI $=.97, \mathrm{CFI}=.99$, AGFI $=.95$, RMSEA $=.08$ ). Although correlating errors is often criticized as a form of post-hoc fitting, both theoretical and statistical evidence discussed by McDonald and Ho (2002) guide our view that the two correlated disturbances in our model do not result from mere capitalization on chance. From a statistical standpoint, we were able to demonstrate that the structure containing the correlated errors replicated across all samples (both combined and individually), which leads us to conclude that this model reflects the true population covariance matrix. Theoretical interpretation of the co-variance among error terms indicates that the revised model more accurately represents the construct. The first correlated disturbance is between items 1 and 3 of the WDSS ("In general, the type of work I do corresponds closely to what I want in life" and "I am satisfied with the type of work I do"); i.e., the only two items in the scale which directly assess respondents' attitude toward their work in particular. Similarly, the second correlated disturbance is between items 2 and 5 ("The conditions under which I do my work are excellent" and "If I could change anything at work, I would change almost nothing") which are broad assessments of respondents' perceptions of work conditions. The final model is depicted in Figure 1. In the model, the path coefficients are standardized and all values are significant at $p<.05$. 


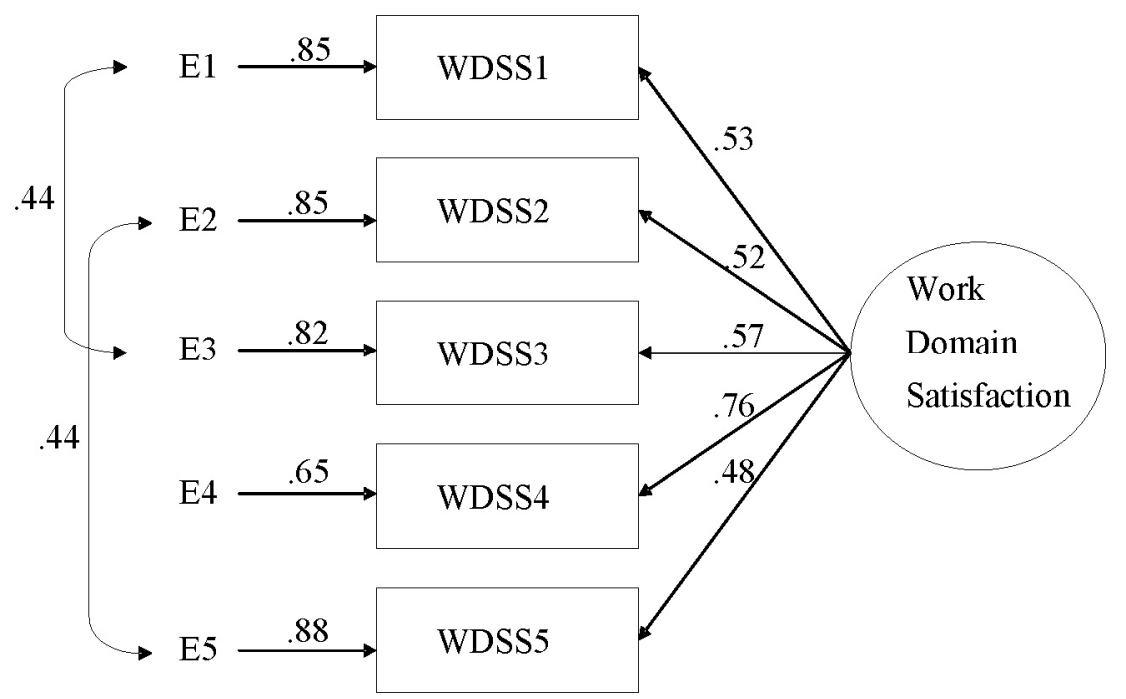

Figure 1. Confirmatory factor analysis of the WDSS (6 samples combined)

\subsection{Invariance Analyses}

We completed invariance analyses (Vandenberg \& Lance, 2000) across the six samples, and then across the two languages. Results of the multi-sample invariance analysis indicate that despite placing equality constraints on all appropriate factor loadings including the two error covariances, the multi-sample model underwent minimal deterioration in model fit (corrected $\Delta \mathrm{S}-\mathrm{B} \chi^{2}=198.54, p<.01 ; \Delta \mathrm{NNFI}=.07 ; \Delta \mathrm{CFI}=.06$ ). Overall, the model exhibited a good fit to the data $(\mathrm{NNFI}=.93 ; \mathrm{CFI}=.94$; RMSEA $=.08,90 \%$ C.I. $=.07, .097)$. Detailed examination of equivalence across parameters was undertaken to further determine equivalence across groups. Review of the univariate $\chi^{2}$ values that are $<.05$ did not identify parameters exhibiting non-equivalence among all samples.

Results of the multi-language invariance analysis indicate that despite placing equality constraints like in the previous analysis, the model underwent minimal deterioration in fit (corrected $\Delta \mathrm{S}-\mathrm{B} \chi^{2}=53.69, p<.01 ; \Delta \mathrm{NNFI}$ $=.02 ; \Delta \mathrm{CFI}=.01)$. Overall, the model exhibited a good fit to the data $(\mathrm{NNFI}=.97$; CFI $=.98 ; \mathrm{RMSEA}=.05$, $90 \%$ C.I. $=.04, .07)$.

\subsection{Temporal Stability}

We evaluated the temporal stability of the WDSS over a six month period (Sample 1) and obtained a test-retest reliability of $r=.77, p<.01$. For the same sample, we obtained a test-retest reliability of $r=.82, p<.01$ for the SWLS. These results show that the WDSS is a relatively stable construct over time and that its stability is comparable to the SWLS.

\subsection{Discriminant Validity}

\subsubsection{Work Domain Satisfaction and Satisfaction with Life}

We tested the discriminant validity between WDSS and the SWLS by conducting a CFA using the data from Sample 1, and compared the fit of a one-factor versus a two-factor model. The one-factor model represented the variables of both scales as indicators of a single construct, while a two-factor model loaded the variables on each of their correspondingly separate measures. Fit indices obtained for each model indicate that the two-factor model yielded a better fit $\left(\chi^{2}=68.39, p=.001 ; \mathrm{GFI}=.92 ; \mathrm{NFI}=.95, \mathrm{CFI}=.97 ; \mathrm{NNFI}=.96 ; \mathrm{SRMR}=.05 ; \mathrm{RMSEA}=.07\right)$ over the one-factor model $\left(\chi^{2}=294.49, p=.001\right.$; GFI $=.73$; NFI $=.78, \mathrm{CFI}=.80$; NNFI $=.74$; $\mathrm{SRMR}=.12$; RMSEA $=.19$ ). Discriminant validity was tested through the correlation between the two latent constructs of WDSS and SWLS in the last CFA analysis. The correlation was .72, which suggests work domain satisfaction is a related but distinct construct from general life satisfaction. 


\subsubsection{Work Domain Satisfaction and Job Satisfaction}

Having established evidence of discriminant validity between the WDSS and the higher hierarchical level satisfaction construct, we proceeded to test the discriminant validity between WDSS and the lower hierarchical level satisfaction construct, job satisfaction, measured with the OJS. We began by testing the validity of our assumptions about the distinctions between job satisfaction and work domain satisfaction by asking 48 employed students enrolled in business administration classes to match the WDSS items and the five items from the abridged OJS with the stems for each of these instruments. Correct item-stem matches ranged from $64.2 \%$ to $83.3 \%$ for the WDSS, with an overall of $76.7 \%$ correct matches. For the OJS, item-stem matches ranged from $71.4 \%$ to $80.9 \%$, with an overall of $75.7 \%$ correct matches. Therefore, raters generally matched the items with the correct instrument, and the percentage of correct item-stem matches between the OJS and the WDSS was comparable. Respondents in Samples 5 and 6 both reported an average work domain satisfaction slightly lower (Mean, Sample $5=3.53$; Sample $6=4.77$ ) than their average job satisfaction (Mean, Sample $5=3.80$; Sample $6=5.47$ ).

Subsequently, we conducted a CFA using the data from Sample 6 to compare the fit of a one-factor versus a two-factor model. We obtained good internal consistency reliabilities for both the WDSS (Cronbach's alpha $=.87$ ) and the OJS (Cronbach's alpha $=.83$ ). The one-factor model represented the variables of both scales as indicators of a single construct, while a two-factor model loaded the variables on each of their correspondingly separate measures. Fit indices obtained for each model indicate that the two-factor model yielded a better fit $(\chi 2=77.97, p$ $=.001 ; \mathrm{GFI}=.91 ; \mathrm{NFI}=.89, \mathrm{CFI}=.94 ; \mathrm{NNFI}=.92 ; \mathrm{SRMR}=.05 ; \mathrm{RMSEA}=.09)$ over the one-factor model $(\chi 2$ $=163.71, p=.001 ; \mathrm{GFI}=.79 ; \mathrm{NFI}=.78, \mathrm{CFI}=.81 ; \mathrm{NNFI}=.76 ; \mathrm{SRMR}=.08 ; \mathrm{RMSEA}=.16) . \mathrm{GFI}$, NFI, CFI and NNFI indices for the two-factor model were near or exceeded the minimally accepted value of .90 (Bentler, 1992; Klein, 1998). Although SRMR and RMSEA indices for the two factor model indicated marginally adequate fit (Hu $\&$ Bentler, 1999), these nonetheless represented a significant improvement over the corresponding indices for the one-factor model. Furthermore, the correlation between the constructs in the last CFA was .62. The results support the notion that work domain satisfaction is a related but distinct construct from job satisfaction and thus, that the WDSS measures a related but distinct construct from the OJS.

\subsection{Convergent Validity}

To verify whether the WDSS is associated with constructs related to work, we included from the study for Sample 2 an assessment of inclusion of work into the self, which is an indicator of work importance. The results showed a positive correlation between the WDSS and inclusion of work in the self $(r=.24, p<.05)$.

Furthermore, we verified whether the WDSS was related to another work-related psychological construct perceived work competence. Results showed that the WDSS was positively associated with perceived work competence in both Sample $3(r=.61, p<.01)$ and Sample $4(r=.31, p<.01)$.

Previous research had established a clear positive relationship between job satisfaction and affective organizational commitment (Meyer et al., 2002). Since the work domain, as the higher level construct, includes people's jobs, we expected the relationship between the WDSS and affective organizational commitment to be in the same direction as the relationship between the OJS and affective organizational commitment. The results showed that the WDSS was positively related to affective organizational commitment in Sample $3(r=.18, p<.05)$ and $6(r=.49, p<.01)$. In Sample 6 , the association between the OJS and affective organizational commitment was also positive and just slightly lower $(r=.41, p<.01)$.

\subsection{Variance Explained}

After establishing that both the WDSS and the OJS were positively related to affective organizational commitment, we used the data from Sample 6 to conduct multiple regression analyses to determine the amount of variance in affective organizational commitment explained by each construct. When both were entered in a regression, the WDSS and the OJS combined explained $26.2 \%$ of the variance in affective organizational commitment $(p<.001)$ and the WDSS explained a significant amount of additional variance in affective organizational commitment $\left(\Delta R^{2}\right.$ $=0.092, p<.001)$ beyond that of job satisfaction. Beta weights indicate that in this sample, work domain satisfaction $(\beta=.306, p<.001)$ was a stronger predictor of affective organizational commitment than job satisfaction $(\beta=.155, p<.05)$. 


\section{Discussion}

\subsection{Major Contributions of the Study}

Prior investigations (Lévesque et al., 2004a, 2004b) using a French version of the WDSS surveyed employed people and focused on their paid work, rather than on the work domain. Therefore, the instrument was employed to evaluate a form of job satisfaction, rather than work domain satisfaction. Like these previous studies, we considered the instrument as a way to measure job satisfaction but also sought to clarify whether it may be more useful as a mid-level measure. With the addition of factor analytic results, our findings concur with those of previous studies that the WDSS is distinct from the SWLS, but that these are related constructs. Furthermore, we demonstrated with confirmatory factor analyses that the WDSS had a one-factor structure with some correlated errors, and our invariance analyses indicated that this model was stable across languages and samples. Moreover, our factor analytic findings provide evidence that the WDSS measures a construct distinct from overall job satisfaction. Finally, our results contributed new evidence regarding the temporal stability and invariance of the WDSS across samples and two languages.

\subsection{Hierarchical Evidence}

\subsubsection{Stability Evidence}

Comparing the stability of the WDSS with that of higher and lower-level constructs helps situate it hierarchically. Our results indicate that the WDSS is a relatively stable construct over time, although it is somewhat less stable than the SWLS. However, the WDSS appears to be at least as stable, or more stable, than most multi-item global job satisfaction scales. Although test-retest reliabilities for multi-item global job satisfaction scales are often not reported (van Saane, Sluiter, Verbeek, \& Frings-Dresen, 2003), Motowildo (1984) reported a test-retest reliability of .79 for a 10-item tailor-made global scale, after a period of 1-3 weeks. However, the high test-retest reliability in this case may have been due to the short time span. Orpen (1978), who used the 18-item OJS over a 12-month time span, reported test-retest reliabilities of 0.27 for a sample of white South African managers. These results suggest that the temporal stability of the WDSS appears to lie between that of the SWLS and that of multi-item global job satisfaction measures. This is congruent with the idea that in hierarchical models, the global level is more stable than the domain level, which is more stable than the state level (Vallerand, 1997).

\subsubsection{WDSS and SWLS}

Previous research had established the French version of the WDSS as distinct from the SWLS. Our research supports these finding and in addition, provides evidence for distinctiveness in both English and French. Prior research had also documented stronger correlations between the WDSS and clear work-related constructs than between the SWLS and these constructs. For example, Lévesque and colleagues (2004a) found a stronger relationship between work conditions on the job and the WDSS $(r=.51, p<.001)$, compared to the SWLS $(r$ $=.32, p<.001$ ). Their second study (Lévesque et al., 2004b) documented stronger relationships between work motivation and the WDSS $(\mathrm{r}=.52, \mathrm{p}<.001)$ compared to the SWLS $(\mathrm{r}=.28, \mathrm{p}<.01)$, and between conscientious OCB and the WDSS $(r=.25, \mathrm{p}<.01)$, compared to the SWLS $(\mathrm{r}=-.01$, ns). This is evidence of the hierarchical placement of the WDSS in relation to life satisfaction. Going further, we established with CFA that the WDSS was a related but distinct construct from the SWLS.

\subsubsection{WDSS and OJS}

No other study had sought evidence of the hierarchical placement of the WDSS relative to job satisfaction. Our CFA provided evidence that the WDSS is a related but distinct construct from the OJS and thus, this supports its placement as a measure of a mid-level construct, between life and job satisfaction. Respondents in Samples 5 and 6 both reported an average work domain satisfaction slightly lower (Mean, Sample $5=3.53$; Sample $6=$ 4.77) than their average job satisfaction (Mean, Sample 5 $=3.80$; Sample $6=5.47$ ). It is not surprising that the employed students in Sample 5 reported lower satisfaction levels with their jobs than the full-time employees in Sample 6. The respondents from Sample 5 occupied largely temporary positions while attending university full-time whereas the respondents in Sample 6 had full-time jobs with better benefits, most likely had more opportunities for advancement, and overall, more sources of satisfaction than the students. Interestingly, in both of these samples, work domain satisfaction was on average lower than job satisfaction. Lower work domain satisfaction compared to job satisfaction may suggest that the job contributes more positively to the person's life and well-being than non-job work activities. A possible explanation might be that in previous research, the prevalent non-job work people typically engaged in was housework, which is well-recognized as less satisfying than other types of work activities (e.g., Eichler \& Matthews, 2007; Evansa \& Steptoeb, 2002; Gjerdingen et al., 2001, 2005). 


\subsection{Convergent Validity}

We also found evidence of convergent validity of the WDSS with work-related measures. The WDSS was positively related to inclusion of work into the self, a measure that indicates how involved people are with their work. Furthermore, we found it was positively related to a measure of perceived work competence, another psychological construct related to feelings about work. In addition, the WDSS, like the OJS, was positively related to affective organizational commitment in our samples. This is evidence that the WDSS was related in predictable ways to work-related constructs. Interestingly, the correlation between the WDSS and affective organizational commitment in Sample 6 was slightly stronger than between the OJS and affective organizational commitment. Furthermore, our variance analysis indicated that in this sample, work domain satisfaction $(\beta=.306, p<.001)$ was a stronger predictor of affective organizational commitment than job satisfaction $(\beta=.155, p<.05)$. Affective organizational commitment is a measure that relates specifically to the job. Since the work domain includes the job, we expected this variable to be related to the WDSS, but we also expected the strength of the relationships between the two job-related constructs to be stronger. However, since job satisfaction is part of the work domain, the results may reflect the strength of the higher level construct relative to the lower level construct. Further research on larger samples may help clarify these relationships.

\section{Limitations and Directions for Future Research}

Our findings indicate that measuring differences in work domain and job-specific satisfaction can help assess the relative state of well-being on the job and its contribution to people's fulfilment within the work domain. Although work domain satisfaction was lower than job satisfaction in our samples, it is also possible that the opposite might be found in different samples and research in other contexts is needed to investigate this possibility. For example, people whose skills are underutilized on the job may find greater satisfaction in work accomplished outside the job, such as volunteer work, or academic work. In such cases, work satisfaction may be higher than job satisfaction. Such results would justify the need to investigate further the sources of satisfaction and dissatisfaction in order to identify, if possible, job redesign options to increase job satisfaction.

Due to the nature of the studies involved, we were not able to include variables that would test the predictive validity of the WDSS with a number of relevant domain-level outcomes. Likely directions for such research should include outcomes such as physical health, psychological health (e.g., a sense of accomplishment and self-worth), likelihood of involvement in social support work, or family harmony. Future research is also needed to better map what this measure predicts; to further clarify its position as a complement to job satisfaction measures, and to test the predictive validity of the WDSS relative to other outcomes.

We argued that engaging in work activities that are congruent with one's values can help contribute to a sense of well-being within the work domain. Future research on the predictive validity of the WDSS could help identify the predictors and clarify the process through which individuals manage this sense of value congruence. In addition, we have argued that evaluating satisfaction with the work domain depends on the individual's personal conception of what should be included in it. Therefore, personal choices and perceptions are particularly compelling aspects of defining the work domain which future research needs to address.

Although we validated the WDSS with several samples, additional research is needed to determine whether this instrument is stable across jobs and over periods of time longer than six months. Research is needed to provide evidence of the predictive validity of the scale.

The WDSS is a global scale, which provides a snapshot of work domain satisfaction. However, its global nature cannot capture complex relationships between various types of work. To this end, future research would be required to map the complexity of work roles within the work domain and how changes within the work domain affect work-related well-being.

\section{Conclusion}

Our results support the notion that the WDSS is a useful and parsimonious measure of work domain satisfaction. We sought with six distinct samples to broadly capture the relative meaning and application of the word domain satisfaction construct. Overall, our findings indicate that the WDSS provides a good assessment of work satisfaction and that it is distinct from job satisfaction and satisfaction with life. Aside from providing evidence for the stability and reliability of the WDSS, this study makes an important contribution by demonstrating the distinctive properties and utility of the work domain satisfaction construct. Our study thus establishes the utility of further investigations at the work domain level of analysis to help better understand how people manage their work-related well-being. 


\section{Acknowledgments}

Data collection for this research was facilitated through grants from the Fonds Québécois de la Recherche sur la Société et la Culture to the first and fourth authors and a grant from the Social Sciences and Humanities Research Council of Canada to the third author.

\section{References}

Allen, N. J., \& Meyer, J. P. (1996). Affective, normative and continuance commitment to the organization: An examination of construct validity. Journal of Vocational Behavior, 49, 252-276. http://dx.doi.org/ 10.1006/jvbe.1996.0043

Aron, A., Aron, E. N., \& Smollan, D. (1992). Inclusion of other in the self scale and the structure of interpersonal closeness. Journal of Personality and Social Psychology, 63, 596-612. http://dx.doi.org/10.1037/0022-3514.63.4.596

Bentler, P. M. (1992). On the fit of models to covariances and methodology to the Bulletin. Psychological Bulletin, 112, 400-404. http://dx.doi.org/10.1037/0033-2909.112.3.400

Blais, M. R., Lachance, L., Forget, J., Richer, S., \& Dulude, D. M. (1991). L'échelle de satisfaction globale au travail [The global satisfaction with work scale]. Poster presented at the Annual Congress of the Sociéte québécoise pour la recherche en psychologie, Trois-Rivières, Québec.

Blustein, D. L. (2008). The role of work in psychological health and well-being: A conceptual, historical and public policy perspective. American Psychologist, 63, 228-240. http://dx.doi.org/10.1037/0003-066X.63.4.228

Bono, J. E., \& Judge, T. A. (2003). Self-concordance at work: Toward understanding the motivational effects of transformational leaders. Academy of Management Journal, 46, 554-571. http://dx.doi.org/10.2307/30040649

Brayfield, A. H., \& Rothe, H. F. (1951). An index of job satisfaction. Journal of Applied Psychology, 35, 307-311. http://dx.doi.org/10.1037/h0055617

Cammann, C., Fichman, M., Jenkins, D., \& Klesh, J. (1991). The Michigan Organizational Assessment Questionnaire (Unpublished Manuscript). University of Michigan, Ann Arbor.

Connolly, J. J., \& Viswesvaran, C. (2000). The role of affectivity in job satisfaction: A meta-analysis. Personality and Individual Differences, 29, 265-281. http://dx.doi.org/10.1016/S10191-8869(99)00192-0

Diener, E. (1994). Assessing subjective well-being: Progress and opportunities. Social Indicators Research, 31, 103-157. http://dx.doi.org/10.1007/BF01207052

Diener, E., Emmons, R. A., Larsen, R., \& Griffin, S. (1985). The Satisfaction with Life Scale. Journal of Personality Assessment, 49, 71-75. http://dx.doi.org/10.1207/s15327752jpa4901_13

Diener, E., Suh, E. M., Lucas, R. E., \& Smith, H. L. (1999). Psychological Bulletin, 125, 276-302. http://dx.doi.org/10.1037/0033-2909.125.2.276

Eichler, M., \& Matthews, A. (2007). What is work? Looking at all work through the lens of unpaid housework. In L. Tepperman, \& H. Dickinson (Eds.), Reading sociology: Canadian perspectives (pp. 133-136). Don Mills, Ontario, Canada: Oxford University Press.

Evansa, O., \& Steptoeb, A. (2002). The contribution of gender-role orientation, work factors and home stressors to psychological well-being and sickness absence in male- and female-dominated occupational groups. Social Science \& Medicine, 54, 481-492. http://dx.doi.org/10.1016/S0277-9536(01)00044-2

Gjerdingen, D., McGovern P., Bekker, M., Lundberg, U., \& Willemsen, T. (2001). Women's work roles and their impact on health, well-being, and career: Comparisons between the United States, Sweden, and the Netherlands. Women \& Health, 31(4), 1-20. http://dx.doi.org/10.1300/J013v31n04_01

Gjerdingen, D., McGovern, P., Bekker, M., Lundberg, U., \& Willemsen, T. (2005). Taking its toll: The influence of paid and unpaid work on women's well-being. Feminist Economics, 11, 63-94. http://dx.doi.org/10.1080/1354570042000332597

Hoppock, R. (1935). Job Satisfaction. New York: Harper \& Row.

Hu, L., \& Bentler, P. M. (1999). Cutoff criteria for fit indices in covariance structure analysis: Conventional criteria versus new alternatives. Structural Equation Modeling, 6, 1-55. http://dx.doi.org/10.1080/10705519909540118 
Ironson, G. H., Smith, P. C., Brannick, M. T., Gibson, W. M., \& Paul, K. B. (1989). Constitution of a job in general scale: A comparison of global, composite, and specific measures. Journal of Applied Psychology, 74, 193-200. http://dx.doi.org/10.1037/0021-9010.74.2.193

Judge, T. A., Bono, J. E., \& Locke, E. A. (2000). Personality and job satisfaction: The mediating role of job characteristics. Journal of Applied Psychology, 85, 237-249. http://dx.doi.org/10.1037/0021-9010.85.2.237

Judge, T. A., Bono, J. E., Thoresen, C. J., \& Patton, G. K. (2001). The job satisfaction-job performance relationship: A qualitative and quantitative review. Psychological Bulletin, 123, 387-407. http://dx.doi.org/10.1037/0033-2909.127.3.376

Judge, T. A., Heller, D., \& Mount, M. K. (2002). Five-factor model of personality and job satisfaction: A meta-analysis. Journal of Applied Psychology, 87, 530-541. http://dx.doi.org/10.1037/0021-9010.87.3.530

Kelloway, E. K., \& Day, A. L. (2005). Building healthy workplaces: What we know so far. Canadian Journal of Behavioural Science, 37, 223-235. http://dx.doi.org/10.1037/h0087259

Kim, S., \& Feldman, D. C. (2000). Working in retirement: The antecedents of bridge employment and its consequences for quality of life in retirement. The Academy of Management Journal, 43(6), 1195-1210. http://dx.doi.org/10.2307/1556345

Klein, R. B. (1998). Principles and Practice of Structural Equation Modeling. New York: The Guilford Press.

Lévesque, M., Blais, M. R., \& Hess, U. (2004a). Dynamique motivationnelle de l'épuisement et du bien-être chez des enseignants africains [Motivational dynamics in relation to burnout and well-being among African teachers]. Canadian Journal of Behavioural Sciences, 36, 190-201. http://dx.doi.org/10.1037/h0087229

Lévesque, M., Blais, M. R., \& Hess, U. (2004b). Motivation, comportement organisationnels discrétionnaires et bien-être en milieu africain: Quand le devoir oblige? [Motivation, organizational citizenship behaviours and well-being in an African context: When duty obliges?]. Canadian Journal of Behavioural Science, 36, 321-332. http://dx.doi.org/10.1037/h0087240

Lucas, R. E., Diener, E., \& Suh, E. (1996). Discriminant validity of well-being measures. Journal of Personality and Social Psychology, 71, 616-628. http://dx.doi.org/10.1037/0022-3514.71.3.616

McDaid, D., Curran, C., \& Knapp, M. (2005). Promoting mental well-being in the workplace: A European policy perspective. International Review of Psychiatry, 17, 365-373. http://dx.doi.org/10.1080/09540260500238397

McDonald, P. R., \& Ho, M. R. (2002). Principles and practice in reporting structural equation analyses. Psychological Methods, 7, 64-82. http://dx.doi.org/10.1037/1082-989X.7.1.64

McKee-Ryan, F. M., Song, Z., Wanberg, C. R., \& Kinicki, A. J. (2005). Psychological and physical well-being during unemployment: A meta-analytic study. Journal of Applied Psychology, 90, 53-76. http://dx.doi.org/10.1037/0021-9010.90.1.53

Meyer, J. P., \& Allen, N. J. (1991). A three-component conceptualization of organizational commitment. Human Resource Management Review, 1(1), 61-89. http://dx.doi.org/10.1016/1053-4822(91)90011-Z

Meyer, J. P., Allen, N. J., \& Smith, C. A. (1993). Commitment to organizations and occupations: Extension and test of a three-component conceptualization. Journal of Applied Psychology, 78, 538-551. http://dx.doi.org/10.1037/0021-9010.78.4.538

Meyer, J. P., Stanley, D. J., Herzcovitch, L., \& Topolnytsky, L. (2002). Affective, continuance and normative commitment to the organization: A meta-analysis of antecedents, correlates, and consequences. Journal of Vocational Behavior, 61, 20-52. http://dx.doi.org/10.1006/jvbe.2001.1842

Morrison, R. S., Jones, L., \& Fuller, B. (1997). The relation between leadership style and empowerment on job satisfaction of nurses. Journal of Nursing Administration, 27(5), 27-34. http://dx.doi.org/10.1097/00005110-199705000-00007

Motowildo, S. J. (1984). Does job satisfaction lead to consideration and personal sensitivity? Academy of Management Journal, 27, 910-915. http://dx.doi.org/10.2307/255889

Oishi, S., \& Diener, E. (2001). Re-Examining the general positivity model of subjective well-being: The discrepancy between specific and global domain satisfaction. Journal of Personality, 69, 641-666. http://dx.doi.org/10.1111/1467-6494.694158 
Orpen, C. (1978). Work and nonwork satisfaction: A causal-correlational analysis. Journal of Applied Psychology, 63, 530-532. http://dx.doi.org/10.1037/h0078042

Pavot, W., Diener, E., Colvin, C. R., \& Sandvik, E. (1991). Response artifacts in the measurement of subjective well-being. Social Indicators Research, 24, 35-56. http://dx.doi.org/10.1007/BF00292649

Pons, D., Atienza, F. L., Balaguer, I., \& Garcia-Merita, M. L. (2000). Satisfaction with Life Scale: Analysis of factorial invariance for adolescents and elderly persons. Perceptual and Motor Skills, 91, 62-68. http://dx.doi.org/10.2466/pms.2000.91.1.62

Ros, M., Schwartz, S. H., \& Surkiss, S. (1999). Basic individual values, work values and the meaning of work. $\begin{array}{llllll}\text { Applied } & \text { Psychology, } & \text { An }\end{array}$ http://dx.doi.org/10.1111/j.1464-0597.1999.tb00048.x

Ryff, D. D., \& Keyes, C. L. M. (1995). The structure of psychological well-being revisited. Journal of Personality and Social Psychology, 69, 719-727. http://dx.doi.org/10.1037/0022-3514.69.4.719

Smith, P. C., Kendall, L. M., \& Hulin, C. L. (1969). Measurement of Satisfaction in Work and Retirement. Chicago, IL: Rand McNally.

Spector, P. E. (1985). Measurement of human service staff satisfaction: Development of the Job Satisfaction Survey. American Journal of Community Psychology, 13, 693-713. http://dx.doi.org/10.1007/BF00929796

Spector, P. E. (1997). Job satisfaction: Application, assessment, cause, and consequences. Thousand Oaks, CA: Sage Publications.

Spreitzer, G. M. (1995). Psychological empowerment in the workplace: Dimensions, measurement, and validation. Academy of Management Journal, 38, 1442-1465. http://dx.doi.org/10.2307/256865

Spreitzer, G. M. (1996). Social structural characteristics of psychological empowerment. Academy of Management Journal, 39, 483-504. http://dx.doi.org/10.2307/256789

Spreitzer, G. M., \& Quinn, R. E. (2001). A Company of Leaders: Five Disciplines for Unleashing the Power in your Workforce. San Francisco: Jossey-Bass.

Streiner, D. L. (2003) Starting at the beginning: An introduction to coefficient alpha and internal consistency. Journal of Personality Assessment, 80, 99-103. http://dx.doi.org/10.1207/S15327752JPA8001_18

Thomas, K. W., \& Velthouse, B. A. (1990). Cognitive elements of empowerment: An "Interpretive" model of intrinsic task motivation. The Academy of Management Review, 15, 666-681.

Thoits, P. A., \& Hewitt, L. N. (2001). Volunteer work and well-being. Journal of Health and Social Behavior, 42, 115-131. http://dx.doi.org/10.2307/3090173

Vallerand, R. J. (1997). Toward a hierarchical model of intrinsic and extrinsic motivation. In M. P. Zanna (Ed.), Advances in experimental social psychology (Vol. 29, pp. 271-360). San Diego: Academic Press. http://dx.doi.org/10.1016/s0065-2601(08)60019-2

Van Saane, N., Sluiter, J. K., Verbeek, J. H. A. M., \& Frings-Dresen, M. H. W. (2003). Reliability and validity of instruments measuring job satisfaction-A systematic review. Occupational Medicine, 53, 191-200. http://dx.doi.org/10.1093/occmed/kqg038

Vandenberg, R. J., \& Lance, C. E. (2000). A review and synthesis of the measurement invariance literature: Suggestions, practices, and recommendations for organizational research. Organizational Research Methods, 3, 4-70. http://dx.doi.org/10.1177/109442810031002

Walters, V., French, S., Eyles, J., Lenton, R., Newbold, B., \& Mayr, J. (1997). The effects of paid and unpaid work on nurses' well-being: The importance of gender. Sociology of Health and Illness, 19, 328-347. http://dx.doi.org/10.1111/1467-9566.00054

Wang, G., \& Lee, P. D. (2009). Psychological empowerment and job satisfaction: An analysis of interactive effects. Group \& Organizational Management, 34, 271-296. http://dx.doi.org/10.1177/1059601108330089

Weiss, D. J., Dawis, R. V., England, G. W., \& Lofquist, L. H. (1967). Manual for the Minnesota Satisfaction Questionnaire, Minnesota studies for vocational rehabilitation (No. XXII). Minneapolis: Industrial Relations Center, University of Minnesota.

Wrzesniewski, A., Dutton, J. E., \& Debebe, G. (2003). Interpersonal sensemaking and the meaning of work. Research in Organizational Behavior, 25, 93-135. http://dx.doi.org/10.1016/S0191-3085(03)25003-6 


\section{Copyrights}

Copyright for this article is retained by the author(s), with first publication rights granted to the journal.

This is an open-access article distributed under the terms and conditions of the Creative Commons Attribution license (http://creativecommons.org/licenses/by/3.0/). 